\title{
REVISITING THE HISTORICAL CONTEXT SURROUNDING THE DEVELOPMENT OF THE ULTIMATE-ISSUE RULE TO INFORM ITS FUTURE IN SOUTH AFRICAN LAW OF EVIDENCE
}

\section{GP Stevens* \\ EC Lubaale ${ }^{* * * *}$}

Key words: Ultimate-issue rule; historical context; South African law of evidence; child sexual abuse cases

\section{Introduction}

Whenever courts are confronted with issues that cannot be determined on the basis of ordinary judgement and practical experience, the appreciable help of experts in the respective field is always merited. Experts have been permitted to testify in a wide

* Senior Lecturer, Department of Public Law, University of Pretoria.

** Post-doctoral Research Fellow at the Institute of International and Comparative Law in Africa, sponsored by the South African Research Chairs Initiative (SARChI), Department of Public Law, University of Pretoria.

*** The insight of Prof Koos Malan, Department of Public Law, University of Pretoria, and Dr Lore Hartzenberg, clinical psychologist, is acknowledged. 
range of fields. One such field is that of child sexual abuse. In child sexual abuse cases, experts have over the years advanced medical evidence and behavioural science evidence. Generally, the advancement of medical evidence is less controversial. Behavioural science evidence, ${ }^{1}$ however, continues to provoke controversy in terms of its interpretation and application. The issue whether or not behavioural science experts should advance an opinion that treads the path of the ultimate-issue stands out as one that continues to be a topic of intense debate. Presently, in South Africa, there is still scholarly and judicial divergence on the exact place of the ultimate-issue rule when mental health professionals are advancing behavioural science evidence in court. This controversial debate is far from being settled as the arguments of the proponents and opponents of the rule alike are sound and convincing. Since arguments on the exact place of the ultimate-issue rule are often advanced in the abstract, with no detailed reference to the legal history of the rule, it is important to trace the legal history of this rule to inform the debate going forward. In this article, we revisit the history surrounding the development of the ultimate-issue rule. We demonstrate that the fact that this rule largely finds justification in the AngloAmerican jury-based system of trial renders its application in non-jury systems such as South Africa's out of context. We underscore the negative effect of the dogmatic application of the ultimate-issue rule on the full exploitation of behavioural science evidence in child sexual abuse prosecutions. Drawing inspiration from the practice of justice systems like that of the United States of America, where this rule partly finds its home, we make a case for its express abolition.

\section{The scholarly divergence on the exact place of the ultimate-issue rule}

In the absence of a codified system on certain rules of evidence, the eloquent arguments of academics in the field are always persuasive and often fill the gaps arising from the impreciseness of the law. In the course of adjudication of cases, judicial officers can draw on these arguments to inform their decisions. However, where the arguments of academics on a particular un-codified aspect of law are divergent or rather unsettled, then serious problems arise in terms of inconsistencies in application and interpretation. This is seemingly the dilemma that South Africa's system is facing up to with regard to the ultimate-issue rule of exclusion in the law of evidence.

1 This evidence can be adduced by mental health professionals such as psychologists, psychiatrists and social workers. It could equally be advanced by non-mental health professionals such as law enforcement authorities and victim advocates who have experience in dealing with child sexual abuse cases. The opinion offered by experts can serve two purposes, namely first as substantive or diagnostic evidence serving the purpose of resolving the issue of whether or not child sexual abuse occurred. Secondly, it can serve the purpose of providing background or rehabilitative evidence, therein providing a proper context within which to evaluate the testimony of the alleged child sexual abuse victim. 
Freckleton and Selby define the ultimate-issue as "the central question which is the responsibility of the judge or jury to determine - an issue of fact or law". ${ }^{2}$ In principle, the ultimate-issue rule advances the notion that an expert cannot testify on the ultimate-issue to be decided by the court because to do so would be to usurp the function of the jury. This rule has now developed into a technical limitation upon the kind of language that the expert is permitted to use in expressing an opinion. The fear that some courts express about expert conclusions that embrace the ultimate-issue is that the jury will defer to the opinion of the expert and abdicate their decisionmaking duties. Presently, South Africa's legislative framework does not have a codified framework delineating on the exact place of the ultimate-issue rule. This being the case, recourse is often made to scholarly literature and precedents on the subject to inform its exact place. However, the arguments of evidence scholars in South Africa are inconsistent and far from harmonious. Indeed, these inconsistencies have equally reflected in the divergence in the decisions of the court when confronted with behavioural science evidence.

Kenny, though not a South African scholar, is one of the evidence scholars, who decades ago advanced arguments for the application of the ultimate-issue rule when courts are dealing with expert opinion. ${ }^{3}$ Based on the argument that opining on the ultimate-issue usurps the role of the jury, he states that there are three ways in which experts usurp the role of others in the legal process. Firstly, experts may usurp the function of the jury by giving a conclusion on the ultimate-issue in the case rather than providing information to the jury to enable them to reach a more informed conclusion. Secondly, they may usurp the role of the judge, by imposing on the jury their own interpretation of statutory terms such as responsibility. Finally, they may usurp the role of the legislature by giving opinions on general policy in relation to the convictions. This, Kenny argues, leads to the risk of unwarranted weight being given to expert evidence. In effect, the opinion of the expert on the ultimate-issue results in a trial by expert. Melton $e \mathrm{al}^{4}$ similarly argue that mental health professionals should "resist the ultimate-issue question".

In South Africa, advocacy for the application of the ultimate-issue rule, particularly when dealing with the opinion of mental health professionals is well documented. Gilmer, Louw and Verschoor ${ }^{5}$ offer two justifications on why mental health professionals should not offer opinion testimony that touches upon the ultimate-issue. The first one pertains to the ethical dilemma of purporting to be scientific where there are no bases for such pretension. The second pertains to the risk of usurping the role of the jury. Allan and Louw observe that "at a practical level the rule prohibiting psychologists from expressing opinions on ultimate-issues may

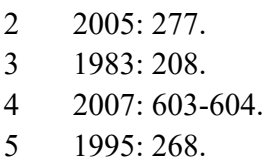


be very important for the fair administration of justice". ${ }^{6}$ Accordingly, they argue that "the profession [of psychology] will be wise to actively discourage its members from giving such opinions. Instead, psychologists should endeavour to write reports which are so informative and complete that asking them to provide an opinion of this nature becomes redundant". ${ }^{7}$ Nelson ${ }^{8}$ shares the sentiments of Allan and Louw, observing as follows:

The courts have been inconsistent in their application of the ultimate-issue rule to expert testimony. I would suggest that much confusion would be avoided, if expert witnesses adhered to their principal role in lending expert evidence to the assessment of the accused's incapacity leaving legal policy to the lawyers. Given the longstanding suspicion and mistrust between these two disciplines, the credibility of expert witnesses would be enhanced if they avoided expressing ultimate opinions unless explicitly asked to do so. ${ }^{9}$

\section{With specific regard to behavioural science evidence in child sexual cases, Songca} is of the view that ${ }^{10}$

[although] behavioural professionals such as psychologists and psychiatrists ... are in a better position to give an opinion or make deductions from proven facts than court itself ...

$6 \quad 1997: 310$.

7 Idem: 318.

8 2012: 27.

9 Nelson's justification for the need to invoke the ultimate-issue rule partly finds basis in the "long standing suspicion and mistrust" between law and the profession of mental health professionals. It is notable that in the past years, the interface between psychology and psychiatry on the one hand and the law on the other hand was laden with conflict. In some cases, lawyers have "accused" mental health experts of making overblown claims and of being willing to modify their testimony to serve social or financial motives. Bersoff 1999: 401 once said this of experts in psychology: "In our courtroom, psychology is still seen as a mysterious inexact discipline ... populated by hired guns who will switch sides and proffer opinions for the right fee and the greatest notoriety." Hagen 1997: xiii went a step further to overdramatise the impact of psychologists in the courtroom in observing that their opinion is full of "anecdotes, errors, flaming overgeneralisations, and inflammatory charges". Hagen in fact suggested that justice systems should "throw the experts out". Nevertheless, over the years, criminal justice professionals have changed their attitudes towards behavioural science and the experts in this field. Without pre-empting the subsequent discussion, with regards to Nelson's justification, the question is: Does the application of the ultimate-issue rule provide holistic solutions to the problem of suspicion? What Nelson's justification for the invocation of the ultimate-issue rule conveniently ignores is the fact that some mental health professionals are properly qualified; they apply the right methodologies and standards in the assessment process, and can be logically consistent when advancing behavioural science evidence, making their conclusions defensible even on an ultimate-issue. Indeed, where the opinion of mental health professionals is not grounded, there is reason for suspicion. Arguably, the solution should be for mental health professionals to offer sound opinion so that it does not trigger suspicion from court, regardless of whether or not it touches upon the ultimate-issue. However the ultimate-issue rule in and of itself does little or nothing to address problems of suspicious opinion.

10 2003: 460-461. 
these experts should not be allowed to give an opinion on the legal or general merits of the case, or proffer an opinion on the ultimate-issues that the court has to decide.

On the other end of the controversy spectrum, scholars outside of South Africa have over the decades made their position against the application of the ultimateissue rule very clear. Wigmore, ${ }^{11}$ for instance, as far back as 1940, argued that the application of the ultimate-issue rule is a "bit of empty rhetoric" as the court is not bound by the opinion of the expert. He added that the rule is "simply one of those impossible and misconceived utterances which lack any justification in principle". Morgan ${ }^{12}$ termed the rule "sheer nonsense" while McCormick ${ }^{13}$ stated that the rule is "unduly restrictive, is pregnant with close questions of application and often unfairly obstructs the party's presentation of his case". Kalven and Zeisel ${ }^{14}$ as well as Simon ${ }^{15}$ went a step further to conduct empirical studies to substantiate the arguments of the proponents of the application of the ultimate-issue rule. Their findings indicated that jurors and judges are not overawed by expert testimony. These authors expressed confidence and faith in courts to independently arrive at decisions without relinquishing their decision-making powers. Bonnie, a defender of psychiatric participation in the criminal process, contends that it is for court to substantiate on the evidence received rather than for experts to be restricted as to the manner in which they are to express opinion. ${ }^{16}$

In South Africa, Zeffert and Paizes ${ }^{17}$ argue that this formulation serves no purpose other than to "obfuscate the true principle". They point out that it is impossible for experts to usurp the function of the court because when all is said and done, the court is free to reject the witness' evidence. Schwikkard and Van der Merwe find the ultimate-issue doctrine puzzling in light of the fact that "[it] fails to explain why courts at times permit not only experts but also lay witnesses to express opinion on the very issue that court has to decide". ${ }^{18}$ Meintjes-Van der Walt shares similar sentiments, arguing that even when a mental health professional adduces evidence that touches upon the ultimate-issue, it remains evidence to be weighed by the court. ${ }^{19}$ Stevens refers to this argument and concludes that when dealing with the evidence of mental health, professionals' opinion testimony should be of less concern. ${ }^{20}$

11 Wigmore as quoted by Branswell 1987: 623.

12 1962: 218.

13 1954: 26.

14 1971: passim.

15 1967: passim.

16 1984: 5-20.

17 2009: 315-318.

18 2010: 83.

19 2001: 236-256.

20 2011: 702. 
In light of the brief discussion above, it can be garnered that controversy heavily abounds as to whether or not the ultimate-issue rule should be invoked when dealing with the evidence of mental health professionals. Indeed, the arguments of opponents and proponents are sound to the extent that consensus cannot be arrived at so easily. Nowhere is the controversy on the application of the ultimate-issue rule more apparent than when dealing with the opinion of mental health professionals. Yet, with this continued controversy, uncertainty will continue to abound with regard to the exact place of the ultimate-issue rule in the advancement of behavioural science evidence. In the advancement of behavioural science in child sexual abuse prosecution, this controversy has already been reflected in two notable 2011 cases. In one of the cases the ultimate-issue rule was applied and in the other, it was not. ${ }^{21}$ The question we should then ask ourselves is: Can we draw from the legal history surrounding the development of this rule to settle this controversial debate? It is the answer to this question that forms the crux of this article.

\section{The legal history surrounding the development of the ultimate-issue rule}

A discussion of the ultimate-issue rule cannot be attempted without a discussion of the history of the opinion rule. The opinion rule of exclusion and the use of expert testimony, like much of the law of evidence, developed out of the adversary system of trial. The rules of exclusion, including the opinion rule, originated in England. ${ }^{22}$ Historically, the opinion rule was designed to prevent witnesses from expressing speculations and persuasions about matters of which they had no personal knowledge. ${ }^{23}$ Witnesses were required to testify as to issues they were certain about. Lord Coke, in his 1622 classic dictum, offered a precise requirement of the rule when he ruled that "[i]t is not satisfactory for a witness to say that he thinketh or persuadeth himself". ${ }^{24}$

Essentially, the moral behind the rule at common law as it was in England was the insistence on reliable forms of evidence rather than testimony based on conjecture. Thus, the English usage of the term "opinion" in the 1700s and earlier, had the meaning of "notion" or "persuasion" of the mind without proof or certain knowledge. It carried an implication of lack of ground. It is against this backdrop that the term "mere opinion" was derived, with a view of disregarding testimony that was not sound, or was ungrounded or unreliable.

In 1766, Lord Mansfield stated the rule against opinion testimony when he concluded that a witness testimony was "mere opinion which was not evidence". ${ }^{25}$ On its face, this rule would appear to bar any testimony deemed opinion as opposed

21 Godi v S [2011] ZAWCHC 247; S v The State [2011] ZASCA 214.

22 Ladd 1952: 414; Sheldon \& Murray 2003: 228.

23 Ladd 1952: 215; Sheldon \& Murray 2003: 227-228; Oliver 2003: 1546.

24 See Adams v Canon (1622) 1 Dyer 53b, 73 ER 117 (KB) (quoted in Ladd 1952: 415).

25 Carter v Boehm (1766) 3 Burr 1905. 
to fact. However, in the 1700s, when Lord Mansfield delivered this dictum, the term "opinion" retained its primary meaning of "notion" or "persuasion" of the mind without proof or certain knowledge. Oliver observes that Lord Mansfield's dictum in 1766 is best understood as a disapproval of unreliable testimony from witnesses who lacked personal knowledge. ${ }^{26}$

It was not until the 1800 s that the opinion rule, dogmatically excluding opinion of witnesses, was established. By the middle of the 1800 s, the disparagement of "mere opinion", but this time not necessarily rooted in unsound and unreliable testimony, had emerged into a canon of exclusion. It furthered the notion that witnesses generally must give facts and not their inferences, conclusions or opinions. This latter approach was a radical departure from the earlier notion which underscored unreliability, unsoundness and conjecture as a basis of exclusion. From the mid1800 s henceforth, the term "opinion" was clothed with new meaning, denoting belief, inference or conclusion. Its classic formulation was based on the assumption that fact and opinion stand in contrast and are distinguishable. For instance, a witness could testify that an alleged child sexual abuse victim was anxious or suffered from post-traumatic stress disorder but could not opine that these reactions can be triggered by child sexual offences. Thus, over the years, the rule developed into a technical limitation upon the kind of language which a witness would be permitted to use in expressing facts which they had personally perceived. In this regard, Ladd has observed that from a historical perspective, the rule was never intended to control the language and manner in which witnesses expressed their testimony. ${ }^{27}$ Mowrer has similarly observed that on account of this history and based on the imprecise use, misapplication and misinterpretation of words, the exclusionary doctrine, now referred to as the "opinion rule", failed to carry forward its intended purpose of exclusion of unsound and unreliable testimony. ${ }^{28}$

Although by the end of the 1800 s common law had rejected testimony of witnesses based on inferences as constituting "mere opinion", courts traditionally made exceptions. One of the exceptions pertained to expert testimony where there was a matter of skill or science to be decided. The courts recognised that the jury might be assisted by the opinion of those peculiarly acquainted with it from their profession or pursuits. But Mowrer adds that just as the imprecise use and application of words led to the extension and distortion of the term "mere opinion", a like imprecision perpetuated the dogmatic and unsound application of the opinion rule exception pertaining to the admissibility of expert evidence. ${ }^{29}$ Even though experts were permitted to offer opinion testimony, it was deemed fit for experts not to opine on the ultimate-issue because to do so would be to usurp the role of the jury. $\mathrm{McCord}^{30}$ has equally observed that the ultimate-issue arose out of the ancient rule

26 2003: 1547.

27 Ladd 1952: 415.

28 1977: 410.

29 Ibid.

30 1987: 74. 
that required that no one should be allowed to give an opinion on any subject. He explains that although courts later begun to relax the rule against opinion testimony, later courts curtailed opinion testimony that touched upon the ultimate-issue as it was deemed to invade the province of the jury. Thus, the form and expression of expert testimony continued to be curtailed even with the opinion testimony exceptions.

Emphasis was placed on the need for experts to resist the ultimate-issue question in offering opinion testimony so as to avoid the risk of overly awing the jury. Thus, "the rule stemmed from concern that jurors might adopt an influential witness's opinion without independently analysing contested facts". ${ }^{31}$ It was argued that expert opinion testimony had a powerful force which could awe the jury to the extent that they would abdicate their decision-making role and consequently prefer the opinion of the expert. ${ }^{32}$ Juries were not trained legal professionals capable of substantiating on critical legal issues and it was only reasonable, as it was argued then, for them to be shielded from the powerful force of opinion testimony that touches upon the ultimate-issue.

The United States of America's system had over the years drawn insight from the exclusionary rules finding origin in England. In the 1800s, America's system first put the ultimate exclusionary rule to the test in the 1840 case of Davis $v$ Fuller $^{33}$ in which the Supreme Court of Vermont excluded the opinion of the expert, ruling that the ultimate-issue regarding the cause of backwater in a river, as it were in this case, was an issue for the jury alone to decide. As such, the court reasoned that expert witnesses may not replace the jury by giving opinions on the point on trial. Soon thereafter, numerous American courts barred witnesses from expressing opinions on ultimate-issues, reasoning that such opinions "invade the province of the jury". Thus, although the ultimate-issue rule was not per se contemplated, it slowly but surely crept in, later becoming a thoroughly grounded technical limitation upon the kind of language which an expert witness would be permitted to use in expressing an opinion. As Maguire has argued, "the real truth is that courts and legislatures, most particularly in [the Anglo-American system] have over the years made up many rules for excluding from trials a great deal of relevant evidence". ${ }^{34}$

\section{$4 \quad$ The history of the jury system in the Anglo-American system and why the application of the ultimate-issue rule was emphasised}

One of the typical features of the Anglo-American system that distinguishes it from many other justice systems, is its jury-based trials. Many of the exclusionary rules in

31 Braswell 1987: 621.

32 Ibid; Kenny 1983: 208; McCormick 1945: 117.

33 Davis v Fuller 12 Vt 178 (1840).

34 As quoted by Kunert 1966-1967: 127. 
the law of evidence find its basis in jury trials. The ultimate-issue rule has, since its inception in the Anglo-American system, found justification in the fact that it usurps the role of the jury. This rule is a reflection of varying and conflicting notions of the jury's mental incapacities to substantiate on evidence without some form of "shield" by way of exclusion of certain forms of confusing evidence. Earlier proponents of this rule were convinced that the jury's mind must not be contaminated by feeding it conflicting evidence that is seemingly difficult to reconcile when arriving at a decision. ${ }^{35}$ The theory was that if the evidence the jury receives is screened for impurities before the jury gets it, jurors would not be confused or overawed. ${ }^{36}$ Given the composition of the jury system as it were when some of these rules were formulated, it is seemingly justifiable that the ultimate-issue rule was considered in the first place.

The English word "juror" comes from the Old French word jurer which means to swear. ${ }^{37}$ The earliest recorded form of jury system is that of Egypt. Beginning around 2000 BCE, ancient Egyptians adjudicated matters through Kenbet, which was comprised of eight jurors consisting of four from each side of the Nile. ${ }^{38}$ In the sixth century BCE, Dikastes, in which designated citizens tried and passed judgment on questions of law, became the norm in Greece. The Greek system evolved into Rome's judices by the fourth century BCE. It was this system that influenced the first form of juries in England, with it arriving on English shores with the Roman conquest. By the late 800 s, under the leadership of Alfred the Great, trial by a jury of one's peers became the norm throughout England.

In England, during the twelfth century, juries were a tool for the king. The earliest recorded juries were employed to discover and present facts in answer to questions addressed to them directly by the king. The jury gave evidence, but only the king or his ministers made the final decision. During the next two centuries, English juries moved from this advisory role to their current role as the decider of facts. By the end of the fifteenth century, the jury system had come to be regarded as the most valuable feature of English common law. Courts at that time began to allow parties to object to certain persons being seated on a jury, usually because they were personal enemies. It was not until the late seventeenth century that a jury could return verdicts. One of the features of England's jury system was the concept of a jury of one's peers. Peers were people with the same general background, chosen at random from members of the community. It was generally believed that a jury of one's peers was better able to understand the nature of the circumstances surrounding a criminal or civil matter based on local experience and could empathise with the parties involved.

\section{See, eg, Kenny 1983: 208.}

Ibid.

See Collins-Robert English French Dictionary 1983.

White 2011: 49; Simon 1975: 1-254; Randolph 2003: xx-xxiv; Alschuler \& Deiss 1994: 867-928. The following paragraphs are based - in general - on these sources. 
However, the jury system quickly spread to the United States. The transplant of the jury system from England to the United States occurred during the American Revolution when most state constitutions adopted the right of jury trials. In the United States of America, the Bill of Rights, written by James Madison, was added to the Constitution in 1791 at the insistence of the states. It explicitly listed the rights of all citizens under the new federal government. These included the right to a jury trial in criminal and civil cases in federal trials. In Africa, the rules of evidence applicable to the jury systems in England became applicable to African countries through reception.

In terms of qualification, jurors were lay people who were generally required to be old enough, in possession of their faculties and of ordinary intelligence. Certain groups were systematically excluded from jury service. For example, it was thought that police officers or lawyers might tend to have a built-in bias about a case or would be too influential with fellow jurors. ${ }^{39}$ In America, in the State of Georgia, a 1797 statute described qualified jurors merely as people qualified to vote. ${ }^{40} \mathrm{In}$ some states during the 1700s jury members were required to have property acquisitions in the form of free holding. ${ }^{41}$ Tucker reported that there are cases in the rural areas of Virginia where jurors were constituted of the idle loiterers about the court. ${ }^{42}$ Similarly, there were several cases in which unqualified citizens were summoned by the sheriffs to act as jurors for formality purposes only. In a notable murder case in 1800 , the judge halted the proceedings after discovering that a deputy sheriff had summoned jurors from a list of twenty-four prospects submitted by the accused's father. ${ }^{43}$ In another case, twelve people who were in a courtroom awaiting trial on a charge of rioting were comprised mostly of the jury panel for the trial of another accused charged with horse-stealing. ${ }^{44}$ The waiting accused thus secured payment for some of their time in court.

Due to the criteria for the selection of juries as well as their qualifications, the jury system was generally depicted in a bad light during the 1800 s and attracted condescending criticism. In Kentucky, in 1858, a critic described jurors as "miserable wretches". ${ }^{45}$ A Georgia newspaper called them "vagabonds". ${ }^{46}$ An observer in Antebellum, Indiana, described jurors as "idle and dissolute persons" and as "loafers

39 Alschuler 1998: 498 observes that the public who served as jurors at the time were less educated than the norm and selection was generally skewed toward the less formal segment of the population.

40 Act to Revise and Amend the Judiciary System, Laws of the State of Georgia, Act of 9 February 1797.

41 Tucker as cited by Alschuler \& Deiss 1994: 880-882.

42 Ibid.

43 Ibid.

44 Ibid.

45 See Ayers 1984: 113.

46 Ibid. 
and drunkards". ${ }^{47}$ In the mid-1800s it was reported that in sixty percent of the criminal trials held in Antebellum Marion County, Indiana, bystanders comprised a majority of all jurors. ${ }^{48}$ Twain noted a case in which it afterwards became apparent that one of the jurors thought incest and arson were the same thing. ${ }^{49}$ Twain is said to have observed at the time that "[America has] a jury system that is superior to any in the world, and its efficiency is only marred by the difficulty of finding twelve men everyday who don't know anything and cannot read". ${ }^{50}$ Boston ${ }^{51}$ also observed as follows:

But in a jury, we have raw recruits who could not as a class do well in any one of the many activities which in civilisation we require from any class in the community. We train recruits to bear arms, we license lawyers, physicians, dentists, midwives, veterinarians, horseshoers, and chauffeurs, but, so long as a man speaks any sort of English, can hear, is on the jury list, and has formed an opinion, he is deemed a competent man to decide disputes in a court of justice ... [I]t is the residue, men of no great responsibility, men whose occupations do not as a rule develop mental acumen, that are left to serve as jurors.

What can be garnered from these reports is that, generally, jurors were depicted as lacking in the understanding of many technical legal issues. It suffices to note that reports about the cognitive inadequacies of jurors at the time coincide with the period when the opinion rule became thoroughly established during the 1800s. With the ultimate-issue rule being born at a time such as this, and when clearly, the risk of jurors being overawed by the more informed experts was present, it is seemingly understandable that the ultimate-issue rule, though untenable in this day and age, was founded in these historical times. The mental inadequacies of jurors at the time played far too great a role in the evidentiary law, including archaic rules such as the so-called ultimate-issue rule. Unfortunately, in the process of transplanting the law which draws its basis from English common law, little regard was had to the fact that some systems, such as that of Africa, are not based on jury trials. In many African systems, including South Africa's, trials are presided over by judges who are versed in the law of evidence.

\section{The redundancy of the ultimate-issue rule in non-jury systems such as that of South Africa}

What is clear in the legal historical exposition above is that the ultimate-issue rule finds its basis in jury systems. Although arguments that expert opinion on the ultimate-issue potentially overawes the jury have been the subject of withering

48 Idem at 86.

49 1872: 342-343.

50 Shapiro 1993: 223.

51 1912: 11-13. 
criticisms, these arguments formed and continue to form the crux of the rule even in non-jury systems. In light of the legal historical context in which the ultimate-issue rule emerged, it is ostensibly reasonable that the rule was considered. Arguably, this rule would make sense if South Africa had jury trials. But the relevance of this rule in non-jury trials, presided over by qualified judges, is questionable. The rule is absurdly inappropriate in any system where there is no jury. Judicial officers are trained in the law of evidence. When judges sit without juries, there is no point in either trying to screen the evidence or issue limiting instructions. Sheldon and Murray correctly observe that screening is superfluous "because the person who does the screening is the very person from whom the evidence is supposed to be screened, and it makes no sense to ask judges to instruct themselves". ${ }^{52}$

It should occasion no surprise that even justice systems such as that of England and the United States of America - which are arguably the "hub" of exclusionary rules - have over the years put these rules to question in light of the changing context. The rules of exclusion, though they developed from practices and expressions of the English and American courts, seem to be applied more flexibly at present in those two countries than in South Africa. In some cases in South Africa, the ultimateissue rule is applied with intense rigor similar to that evident in the $1800 \mathrm{~s}$. It is against this backdrop that it is here submitted that at the very least, the major policy consideration for the need to disregard the ultimate-issue rule should find basis in the fact that South Africa's system does not have jury trials. Precisely put, the judge who is a professional in evaluating evidence should be more readily relied upon to critically sift and weigh evidence which proponents of the application of the rule fear to entrust to a jury. The underlying basis of the rule, namely the usurpation of the role of the jury, does not in fact require the rule in non-jury trials.

The misplacement of received rules such as the ultimate-issue rule is good justification for a reassessment of all received rules. Indeed, no justice system invents all of the legal rules applicable to its system. More often than not, justice systems draw inspiration and insight from rules and doctrines developed elsewhere. The authors, however, caution that the practice of justice systems elsewhere should not be misused by applying them out of context. We endorse the argument of Kanda and Milhaupt who observe that a "fit between the imported rule and the host environment is crucial to the success of a transplant". ${ }^{53}$

Indeed, colonialism had a considerable impact on the development of law in South Africa. South African common law consists of a conglomeration of so-called imposed and received laws made up of a mixture of Roman-Dutch law, English common law as well as South African precedents. English law played a vital role in the process of adaptation especially during the nineteenth and early part of the twentieth centuries. ${ }^{54}$ The courts supplemented and adjusted Roman-Dutch law 
by importing English principles and doctrines. ${ }^{55}$ The law of evidence was equally impacted upon. Zeffert and Paizes observe that when the British forces occupied the Cape in 1806, some of the existing laws were left unchanged. ${ }^{56}$ The authors, however, have correctly observed that a rule of the English law "may be so inappropriate to the South African legal system that it would be wrong slavishly to apply it".

Over the years, some courts in South Africa have rejected the ultimate-rule. ${ }^{57}$ Despite this position, some courts seemingly continue to be haunted by the English common law position on the ultimate-issue rule. ${ }^{58}$ They continue to indiscriminately apply the rule when experts opine on an ultimate-issue. It is in this regard that this received wisdom from the English needs to be revisited.

\section{The present controversy on the exact place of the ultimate-issue rule in the advancement of behavioural science evidence in child sexual abuse cases with reference to two selected cases}

\section{Godi v The State 59}

The 2011 case of Godi $v$ The State pertained to the offence of rape. The facts of the case were that the appellant lived with her grandmother. The appellant worked in a tuck shop close to where the complainant and her grandmother stayed. As such the appellant and the complainant were acquainted with each other. The complainant testified about the alleged rape, stating that the rapes, on more than one occasion, took place on Fridays ${ }^{60}$ when her grandmother was away. According to the complainant, on the first occasion of the rape occurrence, the appellant invited her into his room and told her to undress upon which he had sexual intercourse with her. The following occasion was when the appellant asked her to wash dishes. It is not clear when the abuse was first reported. The facts, however, indicate that a report was not made immediately after the first alleged rape. In 2008, the appellant was convicted by the regional court and accordingly sentenced to fifteen years imprisonment. The appellant appealed against sentence and conviction in the High Court.

On appeal, pertaining to the testimony of the complainant, the defense submitted that her evidence was unreliable, contained contradictions and did not establish the

56 2009: 3-29.

57 See, eg, Hollington v Hewthorn [1943] KB 587 (CA); Genturico AG v Fireston SA (Pty) Ltd 1972 (1) SA 589 (A); Godi $v$ [2011] ZAWCHC 247.

58 See, eg, Holtzauzen $v$ Roodt 1997 (4) SA 766 (W); S v The State [2011] ZASCA 214.

59 Godiv The State [2011] ZAWCHC 247.

60 In 2001. 
offence that the appellant was charged with.$^{61}$ The defense further submitted that the learned trial magistrate had misdirected himself in relying upon the evidence of the expert called by the prosecution to adduce behavioural science evidence. ${ }^{62}$

In the proceedings at the Regional Court, the prosecution had called an expert to adduce behavioural science evidence. The expert, an educational psychologist, evaluated the complainant on 4 May 2005 when she was fifteen years of age. ${ }^{63}$ Amongst other sources, the expert had regard to a trauma report prepared by a welfare worker dated 26 March 2001 as well as a letter by an educational psychologist dated 2 June 2005. These two documents did not form part of the expert's written record and were equally not included in the record. The 2001 report of the welfare officer had stated that "there were objective symptoms of traumatisation possibly as a result of sexual molestation, in the form of enuresis, sleep disturbances ...".

With regard to the expert's reference to these documents, the defense argued on appeal that such reference fell foul of the principles pertaining to admissibility of expert evidence as set out by Satchwell J in Holtzhausen v Roodt. Amongst others, the principles in the Holtzhausen case underscore that the expert's opinion should be based on admissible evidence and should not usurp the role of the court. The defense accordingly submitted that the expert's evidence was inadmissible because the expert's opinion was based on inadmissible evidence and equally usurped the role of court by opining on the ultimate-issue. ${ }^{64}$

In addressing this objection, Olivier $\mathrm{J}$ categorically ruled that the expert was obliged to have regard to both documents. ${ }^{65}$ Although the expert had indeed consulted the two documents without them being admitted in evidence, the expert was extensively cross-examined on the results and conclusions drawn in these documents. ${ }^{66}$ The court, in disregarding arguments finding basis in the ultimate-issue rule, ruled that ${ }^{67}$

the fact that the expert drew inferences also as to veracity and truthfulness [of the complainant] does not by itself make the evidence inadmissible - a court is bound to itself examine the facts - which may include expert opinion of the witness - and to draw its own conclusions.

In affirming the role of behavioural science evidence in providing a context within which to evaluate the evidence of the child sexual abuse complainant, the court ruled that the expert gave important evidence with regard to the perception of events by the complainant, both at the time they took place and the time at which the

61 Para 17.

62 Ibid.

63 Para 19. With regard to the evidence of the expert, the Appellate Court made reference to the proceedings in the Regional Court.

64 Ibid.

65 Para 22.

66 Ibid.

67 Para 24. 
complainant testified. ${ }^{68}$ More specifically, the court pointed out that the evidence of the educational psychologist was important in informing the court's decision on the competence and truthfulness of the rape itself. ${ }^{69}$ Essentially, the court paid undue regard to the traditional rule of exclusion requiring a mental health professional not to opine on an ultimate-issue.

With the pace set by the court in the Godi case, any mental health and justice professional would have expected that in advancing behavioural science evidence in child sexual abuse cases, the rule of exclusion based on the so-called "ultimate-issue rule" can be surmounted. This conclusion does not, however, hold true in light of the 2011 decision in $S v$ The State handed down by the Supreme Court of South Africa. The Appellate Court ultimately upheld the decision of the Regional Court.

\section{$62 S v$ The State ${ }^{70}$}

The case of $S v$ The State also pertained to the offence of rape. The facts of the case were that between 2001 and 2002, the appellant allegedly raped his daughter, the complainant, who was twelve years of age at the time. During trial in the Regional Court, the complainant testified against her father, recounting three cases of rape. The first, she said, took place in Glenharvie when she was in Grade 4 and 12 years old. ${ }^{71}$ The second, she said, took place at their home in the Newcastle Flats in Lucas Street in Rustenburg. ${ }^{72}$ The third, according to her evidence, took place at their dwelling in Van Zyl Street, Rustenburg, when she was in Grade 8 (which was during 2002). All three rapes allegedly took place under similar circumstances (the complainant was in bed, her mother was elsewhere, the appellant undressed her, she resisted but was overpowered and the appellant had intercourse with her). The appellant was convicted in the Regional Court on a charge of rape. He was sentenced to fifteen years imprisonment. The conviction and sentence by the Regional Court was confirmed by the High Court. The appellant appealed against conviction and sentence in the Supreme Court. At trial in the Regional Court, the complainant's allegations were denied by the appellant and in the end, the magistrate was confronted with conflicting versions: that of the complainant and the denial of the appellant. Thus, on appeal in the Supreme Court the only issue in the case was whether the appellant had raped the complainant, and not whether she had been raped or sexually molested.

At trial in the Regional Court, the prosecution had called an educational psychologist, who interviewed the complainant and formed certain impressions

68 Para 25.

69 Ibid.

70 [2011] ZASCA 214.

71 Something must be wrong, she was either about 9 and in Grade 4 or 12 and in Grade 7.

72 One may surmise, if the record is read purposively, that this took place while she was in Grade 7 (probably during 2001). 
about her. ${ }^{73}$ The gist of her evidence, as summarised by the magistrate, was that the complainant was unwilling to cooperate or communicate, that she blamed herself for causing a rift in the family, that she was emotionally unstable and lacked confidence and that she hated her father because he was always drunk. As a matter of fact, the education psychologist's report maintained that the complainant had been raped while she was in Grade 4, but did not contain any reference to other instances of rape. On appeal the Supreme Court ruled that the education psychologist's evidence could in no way contribute to the determination of the issue in question - as to whether the appellant had raped the complainant. ${ }^{74}$ The appeal was accordingly upheld and the conviction and sentence set aside.

Admittedly, this case had many inconsistencies which justified the setting aside of the conviction and sentence. However, what is striking about the Supreme Court decision in this case is not the fact that the Supreme Court did not accord due weight to the opinion of the mental health professional, but some of the reasons that the court gave to justify its non-reliance on the mental health professional's opinion. In substantiating on the rules of expert evidence, the court was seemingly inspired by the ultimate-issue rule and consequently adopted an approach different from that in the Godi case. In the State case, Harms J made reference to the case of $S v$ Engelbrecht ${ }^{75}$ wherein Satchwell J had stated as follows: ${ }^{76}$

Courts frequently turn to persons with expertise and skill for assistance. The relevant principles applicable to the admissibility of opinion evidence by experts, including psychologists and social workers, have been set out in numerous authorities. Firstly, the matter in respect of which the witness is called to give evidence should call for specialised skill and knowledge. Secondly, the witness must be a person with experience or skill to render him or her an expert in a particular subject. Thirdly, the guidance offered by the expert should be sufficiently relevant to the matter in issue to be determined by the Court. Fourth, the expertise of any witness should not be elevated to such heights that the Court's own capabilities and responsibilities are abrogated. Fifth, the opinion offered to the Court must be proved by admissible evidence, either facts within the personal knowledge of the expert or on the basis of facts proven by others. Sixth, the opinion of such a witness must not usurp the function of the Court.

Thus, in the State case, the court concluded that the evidence of the behavioural science expert did not satisfy requirements four, five or six. ${ }^{77}$ It suffices to re-echo that requirement six pertains to the evidence of the expert not usurping the function of the court by opining on the ultimate-issue. ${ }^{78}$

73 Para 12. These references refer to the Supreme Court of Appeal Judgment.

74 Para 17.

75 Sv Engelbrecht 2005 (2) SACR $41(\mathrm{~W})$.

76 As cited in Godiv $S$ [2011] ZAWCHC 247 in para 26.

77 Para 19.

78 On balance, the argument here is not that the opinion of mental health professionals should uncritically be given full weight by the court. Rather, it is that the traditional rules of exclusion, particularly the ultimate-issue rule, should not be a basis of excluding relevant behavioural science evidence that has been properly adduced by qualified experts. 


\section{The negative implication of the application of the ultimate-issue rule to the exploitation of behavioural science evidence in child sexual abuse cases}

It is notable that the Holtzhausen case is often cited when courts are finding a basis to invoke the ultimate-issue rule. Indeed, the dictum in this case has been lauded as a good illustration of when to receive and when to reject the opinion of an expert on an issue that the court has ultimately to decide. This dictum has, however, been criticised based on the fact that although the court rightly based its conclusion on considerations of relevancy and achieving the correct result, the court resorted to "the meaningless and pernicious expression of usurping the function of the court" which, when invoked, can potentially impact negatively on the admissibility of the expert evidence or on the weight attached to it. ${ }^{79}$ Indeed, although the principle of relevancy was underscored in the Holtzhausen case, the courts, in drawing inspiration from this dictum, often indiscriminately emphasised the point of usurpation the role of the jury which has been submitted above, is out of step.

The divergence in the decisions of the courts not only in the Godi and State cases, but also in many other cases ${ }^{80}$ demonstrates the general inconsistencies in the application of the ultimate-issue rule when courts are presented with behavioural science evidence in child sexual abuse prosecutions. The application of the ultimateissue rule negatively impacts on the full use of behavioural science evidence in child sexual abuse prosecutions in two ways. First, if the ultimate-issue rule is invoked, relevant behavioural science evidence can be excluded. Secondly, even when behavioural science evidence is admitted, the courts may fail to accord such evidence the appropriate weight. This is a dilemma that warrants redress given that in child sexual abuse cases mental health professionals are bound to tread the path of the so-called "ultimate-issue". McCord ${ }^{81}$ has correctly argued that behavioural science evidence has a tendency of touching upon the credibility of a witness and often, if not always, on the ultimate-issue for determination before the court. It is therefore not unusual for a mental health professional to submit that the child sexual abuse victim's behavioural condition is consistent with child sexual abuse. Nevertheless, where the ultimate-issue rule is applied, mental health professionals may be precluded from submitting opinions to this effect.

Aside from the prejudicial implications of the ultimate-issue rule on the weight and admissibility of behavioural science evidence in child sexual abuse cases, the inconsistencies across the courts on the exact place of the ultimate-issue rule cause uncertainties for mental health professionals who are left speculating on how far reaching their opinion ought to be. Currently, mental health professionals may be

79 Zeffert \& Paizes 2009: 318.

80 Refer to footnotes 57 and 58 on the other cases.

81 1987: 32. 
unsure whether or not they should have a wide scope for adducing their opinions without being weary of this archaic rule. It is notable that although mental health professionals are merely called as witnesses in child sexual abuse cases, their experience in court can either undermine or further their future interface with the justice system. If greater interface between mental health professionals and the justice system is called for within the context of child sexual abuse prosecutions, it is extremely critical for mental health professionals to have a clear understanding of the scope of their (possible) assistance to the courts. This understanding should be precise and clear so that mental health professionals are not left speculating as to the precise scope of their interface with the justice system. Even more critically, unduly restricting the manner in which mental health professionals should adduce their evidence may be unrealistic and consequently account for the exclusion of relevant evidence simply because of undue rigidities.

In sum, the point we make is not that judicial officers should without scrutiny entertain opinions of mental health professionals that touch upon the ultimate-issue. Indeed, where for instance, the opinion of a mental health professional that touches upon the ultimate-issue is adduced by an unqualified professional, is not supported by reliable and sound data, methodology, assessment or standards; is not backed up by sound and logical explanatory power; has a flawed basis; and/or is lacking probative value to the issue of determination before the court, it should certainly be rendered inadmissible by the court or not accorded due weight. Rather, the point we make is that the opinion of a mental health professional should not be subjected to a different standard merely because it touches upon the ultimate-issue. The ultimate standard should be its relevance to the determination of the issue before the court. If the court can receive appreciable assistance from the expert, ultimate-issues should be the least of the court's worries. The other foregoing issues such as qualification and methodology, amongst others, should equally inform the decision of the court.

\section{The case for express abolition of the ultimate-issue rule}

As implicitly demonstrated thus far, the justice system of the United States of America, as that of South Africa, was considerably impacted upon by the English common law, particularly in terms of the application of the rules of evidence. Years of advocacy from opponents on the efficacy of some rules of exclusion in the United States of America only yielded instructive results with the coming into force of the Federal Rules of Evidence promulgated in 1975. Prior to the adoption of these Rules, there were scholarly and judicial divergent views on the exact place of a considerable number of rules of evidence. Even with the persuasive submissions of proponents on the need to discard rules such as the so-called "ultimate-issue rule", some courts persistently applied them. Precisely put, the exact place of the ultimate- 
issue rule remained obscure without express codification. Proponents, however, breathed a sigh of relief with the coming into force of the Federal Rules of Evidence which clarified the position on many of the controversial rules. One of the rules that were dealt with was the ultimate-issue rule. In terms of Rule 704 "an opinion is not objectionable just because it embraces the ultimate-issue".

Taken together, the point we make pertains to the need for South Africa's system to develop a codified framework on admissibility of expert evidence that addresses the contextual gaps in the current discourse of expert evidence and the needs in a non-jury system such as South Africa's. Statutory guidelines should be introduced to strengthen the advancement of behavioural science evidence and expert evidence generally. The statutory rules should be drafted in such a manner as to take cognizance of the fact that South Africa's system does not have jury trials. Furthermore, these statutory guidelines should be couched in such a manner as to assist judicial officers to evaluate expert evidence, including controversial fields such as behavioural science evidence.

Some South African scholars rightly submit that the traditional rules of exclusion, such as the ultimate-issue rule, are strictly speaking not part of South Africa's modern law. ${ }^{82}$ As such, it could be argued that codification is meaningless. However, the failure of the law codes to clarify on these issues only serves to further inconsistencies, confusion and unpredictability. The position of the courts is far from harmonious. A study by Allan and Louw demonstrates that in South Africa some lawyers still apply the rule informally to some degree ${ }^{83}$ Legal practitioners and mental health professionals differ significantly on the role and place of traditional rules of exclusion. With the current divergence of opinion in South Africa, it is not clear whether a mental health professional can opine on the ultimate-issue or otherwise. Precisely put, there is some sort of legal uncertainty on this issue. As Saltzburg ${ }^{84}$ correctly submits, "[t]here is something terribly wrong with a single system that allows cases to be tried differently in different courtrooms, so that different rules govern the way in which the evidence that is necessary to resolve the case will be presented". In light of the uncertainty that continues to abound with regarding many exclusionary rules, the issue that falls to be resolved is whether or not the time has not come for South Africa to develop a comprehensive codified framework on the rules of evidence that, amongst others, expressly abolishes the ultimate-issue rule.

The need for the express abolition of the rule not only gains credence in the fact that its application is misplaced in a non-jury system such as South Africa's, but also that the rule is out of step with modern forensic evidence including the interface between behavioural science and the law in child sexual abuse cases. Thus, although theoretically the rule does not form part of South Africa's law of 
evidence, this position, in its uncodified form, does not coherently match the practice in some courts when evidence of mental health professionals is adduced. Expressly abolishing this rule would seemingly make its demise more apparent. Arguably, an express abolition of the rule would exert pressure on judicial officers to discard it since some judicial officers and legal practitioners persist in invoking it where none exists. The rule should be codified in such a manner as to allow a mental health professional the leniency in giving an opinion. The judicial officer can ultimately still weigh the opinion of the mental health professional in the same way as any other admitted evidence and consequently arrive at an independent decision. During the weighing process, the judicial officer has the discretion to decide which portions of the evidence to regard as relevant or less relevant. Moreover, with codified rules on the admissibility of expert evidence, the interface between mental health professionals and the justice system would be furthered as both mental health professionals and legal practitioners would be able to view the position through the same lens.

It is to be noted, however, that the authors do not conclude, not even remotely, that expressly abolishing the ultimate-issue rule will conclusively address the uncertainty that mental health professionals encounter in advancing evidence in child sexual abuse cases. Indeed, the jurisprudence in justice systems like that of the United States of America, a system which, arguably, has by far the soundest codified system on the rules of evidence, demonstrates that some form of uncertainty still exists for mental health professionals in terms of the inconsistencies in the decisions of the courts on the ultimate-issue. ${ }^{85}$ It should be emphasised that codification does not provide all the answers to evidentiary problems. Nevertheless, as Saltzburg ${ }^{86}$ persuasively argues, "the fact remains that [codified] rules can be most useful". When objections finding basis in the traditional rules of exclusion are raised, legal practitioners can make reference to the codified rules of evidence in substantiation of the ambiguity. Thus, focus on codification should not be understood to portray that codification is the only or even primary tool of furthering certainty. Sensitisation of judicial officers on modern rules of evidence, could, for instance, also contribute to legal certainty in the long run. However, since some judicial officers and legal practitioners persist in constructing rigid exclusionary rules where none exist, codification then becomes a viable alternative.

85 See, eg, People v Jeff 204 Cal App 3d 309, 251 Cal Rptr 135 (5th Dist 1988); Re Sara M 194 Cal App 3d 585, 239 Cal Rptr 605 (3rd Dist 1987); People v Beckley 161 Mich App 120, 409 NW 2d 759 (1987); People v Bowker 203 Cal App 3d 385, 249 Cal Rptr 886 (4th Dist 1988); Smith v State $100 \mathrm{Nev}$ 570, 688 P 2d 326 (1984); State v Cleveland 58 Wash App 634, 794 P 2d 546 (1990); State v Myers 359 N W 2d 604 (Minn 1984); Townsend v State of Nevada 734 P 2d 705 (1987). 1978: 185. 


\section{Conclusion}

The purpose of this article has been to emphasise what justice systems often overlook, namely that the legal history surrounding the development of exclusionary rules such as the ultimate-issue rule makes their continued application a misplaced move in non-jury trails such as South Africa's. Getting to grips with the historical context of the ultimate-issue rule suggests that the rule ultimately impairs rather than fosters justice in non-jury trials. The legal historical development further suggests that the continued application of a rule, originally developed and suited for jury trial processes in a non-jury environment, is an imperfect fit and problematic. In England, where the jury system and exclusionary rules arising therefrom originated, the jury trial survives only as a matter of theoretical practice. Many of the rules of exclusion, including the so-called "ultimate-issue rule" have been laid to rest. The United States of America that makes use of jury trials has equally developed a codified framework of rules of evidence to place some of the archaic common-law rules into proper context. It is seemingly safe to conclude that some of the rules that are still applied in South Africa's system, drawing inspiration and insight from English common law, are misplaced. This is because, based on their historical foundation, it is hard to identify the public policy consideration served by such exclusion. The continued application of the ultimate-issue rule by some courts, as well as many other rules of exclusion that were beyond the scope of this article, raises two questions: Has not the time come for South Africa's system to revisit some of the received wisdom in terms of the rules of evidence? Secondly, should not codification of a coherent framework that contextually takes cognizance of South Africa's non-jury system be part of that reform agenda?

\section{Abstract}

The controversy surrounding the issue whether or not mental health professionals in South Africa should offer opinion testimony that touches upon the ultimate-issue has been ongoing and remains unsettled. This controversy has left the exact place of the ultimate-issue rule in balance hence causing uncertainty. This uncertainty has impacted negatively on the advancement of opinion testimony by mental health professionals. One notable area that has been affected is the one pertaining to child sexual-abuse cases. The authors trace the historical foundations surrounding the development of the ultimate-issue rule. It is demonstrated that the rule finds its basis in justice systems with jury trials, with the aim of the rule having been to ensure that experts do not usurp the role of the jury. Historically, juries were not schooled in law hence the need to screen the evidence they received ensuring that experts' opinions did not awe them to a point of them relinquishing their decision-making powers. In this context, the unsoundness of the rule in non-jury systems such as South Africa's (where decisions are made by judges schooled in law) is underscored. 
It is highlighted that the policy considerations surrounding the development of this rule are not applicable to South Africa. Recommendations are made for its express abolition by way of statutory guidelines.

\section{Bibliography}

Allan, A \& Louw, DA (1997) "The ultimate opinion rule and psychologists: A comparison of the expectations and experiences of South African Lawyers" Behavioural Sciences and the Law 15: $307-320$

Alschuler, Albert \& Deiss, Andrew (1994) "A brief history of the criminal jury in the United States" The University of Chicago LR 61: 867-928

Alschuler, Albert (1998) “Explaining the public wariness of juries” DePaul LR 48: 407-418

Ayers, Edward (1984) Vengeance and Justice: Crime and Punishment in the Nineteenth-Century American South (Oxford)

Bodenhamer, David (1985) The Pursuit of Justice: Crime and Law in Antebellum Indiana (Garland, Texas)

Bonnie, Richard (1984) “Morality, equality and expertise: Renegotiating the relationship between psychiatry and the criminal law" The Bulletin of the American Academy of Psychiatry and the Law 12: 5-20

Boston, Charles (1912) "Some practical remedies for existing defects in the administration of justice" University of Pennsylvania LR 61: 11-13

Braswell, Anne Lawson (1987) "Resurrection of the ultimate-issue rule: Federal rule of evidence 704 (b) and the insanity defense" Cornell LR 72(3): 620-640

Collins-Robert English French Dictionary (accessed 7 Jan 2016) available at http://www. collinsdictionary.com/dictionary/english

Dubois, Francois (2004) “Introduction: History, system and sources” in Van der Merwe, CG \& Du Plessis, J (eds) Introduction to the Law of South Africa (The Hague): 1-53

Freckleton, Ian \& Selby, Hugh (2005) Expert Evidence - Law Practice, Procedure and Advocacy (North Ryde-Australia)

Gilmer, BT, Louw, DA \& Verschoor, T (1995) "Forensic expertise: The psychological perspective" South African J of Criminal Justice 8: 259-270

Kalven, Harry \& Zeisel, Hans (1971) The American Jury (Chicago, Ill)

Kanda, H \& Milhaupt, CJ (2003) "Re-examining legal transplants: The director's fiduciary duty in Japanese corporate law" The American J of Comparative Law 51: 887-901

Kenny, Anthony (1983) “The expert in court” Law Quarterly $R$ 99: 197-216

Kunert, Karl (1966-1967) "Some observations on the origin and structure of evidence rules under the common law system and the civil law system of free proof in the German code of criminal procedure" Buffalo LR 16: 122-164

Ladd, Mason (1952) "Expert testimony" Vanderbilt LR 5: 414-431

McCord, D (1987) "Syndromes, profiles and other mental exotica: A new approach to the admissibility of non-traditional psychological evidence in criminal cases" Oregon LR 66: 19-108 
McCormick, Charles (1945) "Some observations upon the opinion rule and expert evidence" Texas LR 23: 109-136

McCormick, Charles (1954) Handbook of the Law of Evidence (Minnesota, Minn)

Meintjes-Van der Walt, Lirieka (2001) “A few plain rules? A comparative perspective on exclusionary rules of expert evidence in South Africa" THRHR 64: 236-256

Melton, GB, Petrila, J, Poythress, NG \& Slobogin, C (2007) Psychological Evaluations for the Court (New York, NY)

Morgan, Edmund (1962) Basic Problems of Evidence (Philadelphia, Pa)

Mowrer, John Michael (1977) “Opinion rule as a rule of preference: Application to extrajudicial declarations" Missouri LR 42: 409-427

Nelson, Diane (2012) Non-pathological Criminal Incapacity in South Africa - A Disjunction between Legal and Psychological Discourse? A Case Study (Cape Town)

Oliver, A Ross (2003) "Testimonial hearsay as the basis for expert opinion: The intersection of the confrontation clause and Federal Rule of Evidence 703 after Crawford v Washington" Hastings LJ 55: 1539-1562

Randolph, John (2003) The American Jury System (Michigan, Mich)

Saltzburg, Stephen (1978) "The Federal Rules of Evidence and the quality of practice in Federal Courts" Cleveland State LR 27: 173-194

Schwikkard, PJ \& Van der Merwe, SE (2010) Principles of Evidence (Wetton)

Shapiro, Fred (1993) Oxford Dictionary of Legal Quotations (Oxford)

Sheldon, John \& Murray, Peter (2003) "Rethinking the rules of evidentiary admissibility in nonjury trials" Judicature 86: 227-231

Simon, Rita James (1967) The Jury and the Defense of Insanity (Boston, Mass)

Simon, Rita James (1975) The Jury System in America: A Critical Overview (Beverly Hills, Calif)

Songca, Rushiela (2003) Aspects of Sexual Abuse of Children: A Comparative Study (LLD Thesis, University of Pretoria)

Stevens, Geert Philip (2011) The Role of Expert Evidence in Support of the Defence of Criminal Incapacity (LLD Thesis, University of Pretoria)

Twain, Mark (1872) Roughing It (New York, NY)

White, BA (2011) "Inherent and invaluable: A history of trial by jury" The Advocate: 47-50

Zeffert, T David \& Paizes, A (2009) The South African Law of Evidence (Johannesburg)

\section{Cases}

Adams $v$ Canon (1622) 1 Dyer 53b, 73 ER 117 (KB)

Carter v Boehm (1766) 3 Burr ER

Davis v Fuller 12 Vt 178 (1840)

Genturico AG v Firestone SA (Pty) Ltd 1972 (1) SA 589 (A)

Godi v $S$ [2011] ZAWCHC 247

Hollington $v$ Hewthorn \& Co Ltd [1943] KB 587 (CA)

Holtzhauzen v Roodt 1997 (4) SA 766 (W) 


\section{REVISITING THE HISTORICAL CONTEXT}

People v Beckley 161 Mich App 120, 409 NW 2d 759 (1987)

People v Bowker 203 Cal App 3d 385, 249 Cal Rptr 886 (4th Dist 1988)

People v Jeff 204 Cal App 3d 309, 251 Cal Rptr 135 (5th Dist 1988)

Re Sara M 194 Cal App 3d 585, 239 Cal Rptr 605 (3rd Dist 1987)

$S v$ Engelbrecht 2005 (2) SACR 41 (W)

$S v$ The State [2011] ZASCA 214

Smith v State $100 \mathrm{Nev} 570,688$ P 2d 326 (1984)

State v Cleveland 58 Wash App 634, 794 P 2d 546 (1990)

State v Myers 359 N W 2d 604 (Minn 1984)

Townsend $v$ State of Nevada 734 P 2d 705 (1987)

\section{Statutes}

Act to Revise and Amend the Judiciary System, Laws of the State of Georgia, Act of 9 February 1797 